\title{
PKM STIMULASI TUMBUH KEMBANG MENTAL ANAK USIA DINI UNTUK MENCAPAI TUMBUH KEMBANG YANG OPTIMAL DI PAUD/TK ZAID BIN TSABIT BANGKINANG
}

\author{
Alini $^{1}$, Indrawati ${ }^{2}$, Rinda Fithriyana ${ }^{3}$ \\ Program Studi Sarjana Keperawatan, Fakultas Ilmu Kesehatan, Universitas Pahlawan Tuanku Tambusai \\ e-mail: alini_09@yahoo.com
}

\begin{abstract}
Abstrak
Perkembangan anak dipengaruhi berbagai faktor yang satu sama lain saling mempengaruhi, antara lain: stimulasi yang diterima anak sejak bayi, kematangan anak pada saat menerima stimulasi, sifat-sifat bawaan dari anak, sikap orang tua terhadap anak atau bayi dan interaksi antara orang tua terhadap anak. PAUD/TK Zaid Bin Tsabit merupakan salah satu tempat pendidikan anak usia dini yang berada di Kecamatan Bangkinang. Berbagai macam metode pendidikan telah diterapkan di PAUD/TK Zaid Bin Tsabit, akan tetapi stimulasi perkembangan mental akan secara khusus belum pernah dilakukan. Anak usia dini di PAUD/TK Zaid Bin Tsabit sangat memerlukan stimulasi perkembangan mental untuk mencapai pertumbuhan dan perkembangan yang optimal. Oleh sebab itu kegiatan stimulasi tumbuh kembang mental anak melalui terapi kelompok terapeutik dipandang perlu dilakukan untuk meningkatkan pertumbuhan dan perkembangan mental anak di PAUD/TK Zaid Bin Tsabit. Pelaksaaan stimulasi tumbuh kembang mental anak melalui terapi kelompok terapeutik dilakukan dalam 7 sesi. Dari hasil evaluasi kegiatan didapatkan bahwa sebagian besar guru mampu melakukan stimulasi tumbuh kembang mental anak usia dini melalui kegiatan terapi kelompok terapeutik. Keluarga dan guru hendaknnya melakukan stimulasi secara terus menerus dan berkesinambungan untuk mencapai perkembangan usia dini yang optimal.
\end{abstract}

\section{Kata kunci: Stimulasi, Tumbuh Kembang, Terapi Kelompok Terapeutik, Anak Usia Dini}

\begin{abstract}
Child's development is influenced by various factors that mutually influence each other, including: stimulation received by the child since infancy, maturity of the child when receiving stimulation, inherited traits of the child, parental attitudes towards children or infants and interactions between parents towards children. PAUD / TK Zaid Bin Tsabit is a place for early childhood education in Bangkinang District. Various methods of education have been applied in PAUD / TK Zaid Bin Tsabit, but the stimulation of mental development in particular has never been done. Early childhood in PAUD / TK Zaid Bin Tsabit desperately needs mental development stimulation to achieve optimal growth and development. Therefore the stimulation activities of children's mental growth and development through therapeutic group therapy are seen as necessary to improve the growth and mental development of children in PAUD / TK Zaid Bin Tsabit. Implementation of children's mental growth and development through therapeutic group therapy was carried out in 7 sessions. From the results of the evaluation of the activity, it was found that most of the teachers were able to stimulate early childhood mental growth and development through therapeutic group therapy activities. Families and teachers should stimulate continuously and continuously to achieve optimal preschool age development.
\end{abstract}

Keywords: Stimulation, Growth And Development, Therapeutic Group Therapy, Early Childhood 


\section{PENDAHULUAN}

Masa kanak-kanak merupakan masa yang penting dalam proses perkembangan hidup manusia. Anak-anak pada usia dini merupakan masa emas perkembangan (golden age) dimana terdapat lonjakan perkembangan pada anak yang tidak terjadi pada tahun-tahun sebelumnya. Berdasarkan hasil penelitian, tingkat kapabilitas kecerdasan anak mencapai 50\% pada usia 4 tahun. Pada usia 8 tahun mencapai $80 \%$, dan sisanya diperoleh saat anak berusia 8 tahun keatas (Direktorat Pendidikan anak Usia Dini, 2010). Untuk mengoptimalkan perkembangan anak-anak, maka perlu adanya stimulasi yang sesuai dengan perkembangan anak.

Keberhasilan setiap tahap perkembangan menjadi pondasi bagi tahap perkembangan selanjutnya. Baik buruknya pengalaman di masa kanak-kanak akan menentukan sikap mental anak tersebut setelah ia menjadi dewasa, karena itu perlu memperhatikan tingkah laku dan sikap mental ataupun kebiasaannya, agar dapat dihindarkan hal-hal yang tidak diinginkan. Dengan demikian terlihat betapa pentingnya memberikan perhatian khusus terhadap anak-anak yang sedang mengalami fase pertama di dalam perkembangannya menjadi orang dewasa.

Perkembangan anak dipengaruhi berbagai faktor yang satu sama lain saling mempengaruhi, antara lain : stimulasi yang diterima anak sejak bayi, kematangan anak pada saat menerima stimulasi, sifat-sifat bawaan dari anak, sikap orang tua terhadap anak atau bayi dan interaksi antara orang tua terhadap anak ( Maimunah, 2001)

Stimulasi merupakan rangsangan yang diberikan kepada anak oleh lingkungan, khususnya ibunya, agar anak dapat tumbuh dan berkembang secara optimal. Stimulasi dapat diberikan setiap ada kesempatan bersama anak melalui kegiatan rumah tangga ataupun di luar rumah tangga.

Keperawatan sebagai bagian dari pelayanan kesehatan memegang peranan penting dalam upaya peningkatan perkembangan anak sesuai tugas perkembangan. Berbagai pelayanan kesehatan bisa diberikan oleh perawat baik bersifat umum maupun pelayanan spesialis yang diberikan oleh perawat spesialis jiwa, untuk membantu meningkatkan perkembangan anak. Pelayanan pun mulai diarahkan bukan hanya pada setting rumah sakit yang lebih berorientasi pada upaya kuratif tetapi pada semua tataran pelayanan terutama pada setting komunitas yang lebih berorientasi pada upaya promotif dan preventif. Pada setting komunitas, perawat memberikan pelayanan bukan hanya di Puskesmas tetapi juga pada institusi seperti pada tempat pelayanan anak usia dini yang sudah disebutkan sebelumnya, seperti Taman Kanak-Kanak, Raudathul Athfal, Kelompok Bermain, Tempat Pendidikan Anak, Posyandu, dan keluarga.

PAUD/TK Zaid Bin Tsabit merupakan salah satu tempat pendidikan anak usia dini yang berada di Kecamatan Bangkinang. Berbagai macam metode pendidikan telah diterapkan di PAUD/TK Zaid Bin Tsabit, akan tetapi stimulasi perkembangan mental akan secara khusus belum pernah dilakukan. Anak usia dini di PAUD/TK Zaid Bin Tsabit sangat memerlukan stimulasi perkembangan mental untuk mencapai pertumbuhan dan perkembangan yang optimal. Oleh sebab itu kegiatan stimulasi tumbuh kembang mental anak melalui terapi kelompok terapeutik dipandang perlu dilakukan untuk meningkatkan pertumbuhan dan perkembangan mental anak di PAUD/TK Zaid Bin Tsabit.

Adapun tujuan dari kegiatan pengabdian masyarakat ini adalah untuk meningkatkan pengetahuan guru tentang kebutuhan dan penyimpangan perkembangan anak usia dini (3-6 tahun ) sehingga dapat memberikan stimulasi perkembangan pada anak usia dini dan untuk meningkatkan kemampuan anak dalam mengeksplorasi lingkungannya secara fisik maupun sosial dan mengembangkan inisiatif untuk mulai bertindak.

\section{METODE}

Kegiatan utama kegiatan pengabdian masyarakat ini dilaksanakan selama satu hari dengan rincian kegiatan sebagai berikut:

\section{A. Perencanaan}


Rencana kegiatan telah disusun sejak bulan Januari tahun 2020. Rencana kegiatan akan dilakukan pada bulan Februari di PAUD/TK Zaid bin Tsabit. Dalam masa perencanaan, tim menentukan topik kegiatan pengabdian yang sangat diperlukan oleh sasaran. Dari hasil diskusi dengan tim akhirnya diputuskan bahwa kegiatan pengabdian mengambil tema "Stimulasi tumbuh kembang mental anak usia dini untuk mencapai tumbuh kembang yang optimal". Untuk penentuan sasaran, tim berkoordinasi dengan pihak PAUD/TK Zaid bin Tsabit, dan akhirnya diputuskan bahwa semua murid memerlukan stimulasi tersebut karena seluruh murid di PAUD/TK Zaid bin Tsabit belum pernah secara khusus mendapatkan stimulasi tumbuh kembang mental melalui terapi kelompok terapeutik. Kemudian tim mencoba menghubungi pihak PAUD/TK Zaid bin Tsabit untuk menyampaikan maksud dengan pihak mitra. Mitra sangat setuju dengan kegiatan tersebut.

\section{B. Persiapan}

Kegiatan dilanjutkan dengan pembuatan proposal usulan program untuk diajukan ke Fakultas Ilmu Kesehatan dan kemudian diusulkan ke Lembaga Penelitian dan Pengabdian Kepada Masyarakat (LPPM) Universitas Pahlawan Tuanku Tambusai. Proposal usulan program dibuat sesuai dengan format yang telah ditentukan oleh LPPM.

Tim menyerahkan surat izin pelaksanaan kepada kepala sekolah PAUD/TK Zaid bin Tsabit Bangkinang dan menyepakati hari dan tanggal pasti pelaksanaan kegiatan. Sehari sebelum kegiatan, yaitu hari Senin tanggal 27 Januari 2020. Tim melakukan pertemuan kembali dengan kepala sekolah PAUD/TK Zaid bin Tsabit Bangkinang untuk membicarakan secara operasional terkait dengan pelaksanaan kegiatan ini. Berdasarkan hasil diskusi diputuskan kegiatan akan dilaksanakan pada pukul 09.00 WIB. Kegiatan akan dilakukan di PAUD/TK Zaid bin Tsabit Bangkinang dengan melibatkan seluruh murid PAUD/TK Zaid bin Tsabit Bangkinang. Terkait tempat disiapkan oleh Tim dan kepala sekolah serta guru-guru PAUD/TK Zaid bin Tsabit Bangkinang. Terkait dengan alat dan bahan, Tim mempersiapkan booklet berisi tentang materi stimulasi perkembangan mental anak usia dini dan melakukan peminjaman alat pendukung yang diperlukan ke laboratorium Fakultas Ilmu Kesehatan Keperawatan Universitas Pahlawan Tuanku Tambusai.

Pada hari pelaksanaan, yaitu Selasa tanggal 28 Februari 2020, sejak pukul 09.00 WIB. Kegiatan diawali dengan mengumpulkan seluruh murid PAUD/TK Zaid bin Tsabit, dengan jumlah lansia yang hadir sekitar 42 orang yang didampingi oleh Tim dan kepala sekolah serta guru-guru PAUD/TK Zaid bin Tsabit.

\section{Pelaksanaan}

Pelaksanaan kegiatan pengabdian terlaksana sesuai dengan perencanaan, dimana tepat pukul 09.00 WIB kegiatan pengabdian sudah dimulai. Kegiatan pengabdian berlangsung tanpa halangan yang berarti dan peserta pengabdian mengikuti kegiatan dengan tertib dan interaktif. Kemudian selesai penyampaian materi, acara diakhiri dengan foto bersama seluruh murid dan guru.

Rincian pelaksaaan stimulasi tumbuh kembang mental anak melalui terapi kelompok terapeutik adalah sebagai berikut:

1. Sesi pertama : konsep stimulasi inisiatif anak pra sekolah

Pada sesi ini kegiatan yang dilakukan adalah ketua tim sekaligus pemateri/terapis mendiskusikan pengalaman yang dihadapi oleh guru murid usia dini, kebutuhan tahap tumbuh kembang anak usia dini, (setiap aspek perkembangan mempengaruhi tugas perkembangan inisiatif) penyimpangan perilaku anak usia dini dan bagaimana selama ini memberikan kebutuhan perkembangannya. Hasil dari sesi pertama ini guru mengetahui kebutuhan perkembangan anak usia dini, ciri perkembangan inisiatif, penyimpangan perilaku dan cara mengetasi masalah yang muncul sesuai tahap perkembangan anak usia dini.

2. Sesi kedua : stimulasi motorik kasar dan motorik halus

Pada sesi ini kegiatan yang dilakukan adalah pemateri/terapis mengajarkan stimulasi perkembangan aspek motorik kasar dan halus pada guru-guru. Kegiatan motorik kasar yang 
dilatih yaitu; berjalan di atas papan sempit, melompat tali dan lomba karung. Sedangkan kegiatan motorik halus yang dilatih yaitu menggambar bentuk seperti; bulatan, kotak, matahari, bulan, bintang, rumah dan orang, kemudian menghitung benda kecil seperti kacang tanah dan memasukkannya ke dalam botol.. Stimulasi diberikan melalui bermain tanpa terkesan memerintah anak.

Setelah mengajarkan kepada guru, terapis mempraktikkan langsung cara stimulasi pada anak, kemudian terapis memberi kesempatan pada guru untuk mempraktikkan stimulasi langsung pada anak. Terapis juga meminta guru untuk menyampaikan ke orang tua melatih secara teratur dan memberi kesempatan anak mempraktikkan keterampilan, Terapis juga diharapkan senantiasa memberikan pujian atas keberhasilan keluarga melakukan stimulasi dan keberhasilan anak melakukan keterampilan yang dilatih. Terapis juga mengajarkan guru bagaimana cara memberi pujian atas keberhasilan anak melakukan kegiatan, dan bagaimana memotivasi anak untuk tetap mencoba bila belum berhasil melakukan kegiatan

3. Sesi ketiga : stimulasi kognitif dan bahasa

Pada sesi ini kegiatan yang dilakukan adalah terapis mengajarkan stimulasi perkembangan aspek kogntif dan bahasa pada guru yang meliputi aspek kognitif yaitu : mengelompokkan benda berdasarkan bentuk dan ukuran, mengenal 4 macam warna atau lebih, dan bercerita dengan khayalan.Pada aspek bahasa guru membantu anak usia dini mencapai kemampuan berbahasa yaitu bercerita menggunakan kalimat lengkap dari 3 sampai 4 kata, menyebutkan nama-nama hari dalam seminggu, nama bulan dam mengikuti tiga perintah sekaligus.

Setelah mengajarkan kepada guru, terapis mempraktikkan langsung cara stimulasi pada anak, kemudian terapis memberi kesempatan pada guru untuk mempraktikkan stimulasi langsung pada anak. Terapis juga meminta komitmen guru untuk melatih kemampuan kognitif dan bahasa secara teratur dan memberi kesempatan anak mempraktikkan keterampilan, Terapis juga diharapkan senantiasa memberikan pujian atas keberhasilan keluarga melakukan stimulasi dan keberhasilan anak melakukan keterampilan yang dilatih. Terapis juga mengajarkan guru bagaimana cara memberi pujian atas keberhasilan anak melakukan kegiatan, dan bagaimana memotivasi anak untuk tetap mencoba bila belum berhasil melakukan kegiatan

4. Sesi keempat : stimulasi emosi dan kepribadian

Pada sesi ini kegiatan yang dilakukan adalah terapis mengajarkan stimulasi perkembangan aspek emosi dan kepribadian pada guru. Aspek emosi yang dilatih seperti : mengekspresikan dan beradaptasi dengan emosi yang dirasakan, misalnya; gembira, rasa bangga, takut, dan marah; serta bentuk-bentuk emosi lainnya, melatih anak menunda keinginan/ tidak memaksakan keinginan dan mengucapkan terima kasih atas pemberian orang lain dan meminta maaf bila melakukan kesalahan. Sedangkan aspek kepribadian yang dilatih seperti menyebutkan nama lengkap, nama panggilan, jenis kelamin, mengenal ukuran tubuh, membandingkan dengan teman sebaya serta mampu menerima ukuran tubuhnya, anak juga dilatih untuk mampu tampil di depan umum.

Setelah mengajarkan kepada guru, terapis mempraktikkan langsung cara stimulasi pada anak, kemudian terapis memberi kesempatan pada guru untuk mempraktikkan stimulasi langsung pada anak. Terapis juga meminta komitmen orang tua untuk melatih anak mengenali diri dan emosi serta membantu anak mengekspresikan emosi dan kelebihan diri anak secara tepat. Terapis juga diharapkan senantiasa memberikan pujian atas keberhasilan keluarga melakukan stimulasi dan keberhasilan anak melakukan keterampilan yang dilatih. Terapis juga mengajarkan orang tua bagaimana cara memberi pujian atas keberhasilan anak melakukan kegiatan, dan bagaimana memotivasi anak untuk tetap mencoba bila belum berhasil melakukan kegiatan

5. Sesi kelima : stimulasi moral dan spiritual

Pada sesi ini kegiatan yang dilakukan adalah terapis mengajarkan stimulasi perkembangan aspek moral dan spiritual pada guru yang meliputi aspek moral yaitu; mengikuti aturan 
keluarga, mematuhi aturan kelompok dan menyadari konsekuensinya bila tidak mengikuti aturan tersebut, dan memotivasi anak untuk selalu melakukan perbuatan baik seperti membantu orang lain, tidak bertengkar dengan saudara dan teman, dan tidak berbohong. Pada aspek spiritual guru dilatih mengajarkan anak berdoa yang pendek seperti berdoa sebelum makan, tidur dan sebelum pergi ke luar rumah, melibatkan anak dalam kegiatan ibadah dalam keluarga, serta mendengarkan bacaan atau melatih anak membaca kitab suci.

Setelah mengajarkan kepada guru, terapis mempraktikkan langsung cara stimulasi pada anak, kemudian terapis memberi kesempatan pada guru untuk mempraktikkan stimulasi langsung pada anak. Terapis juga meminta komitmen orang tua untuk bisa menjadi contoh anak dalam perilaku moral dan spiritual, Terapis juga diharapkan senantiasa memberikan pujian atas keberhasilan orang tua melakukan stimulasi dan keberhasilan anak melakukan keterampilan yang dilatih. Terapis juga mengajarkan orang tua bagaimana cara memberi pujian atas keberhasilan anak melakukan kegiatan, dan bagaimana memotivasi anak untuk tetap mencoba bila belum berhasil melakukan kegiatan

6. Sesi keenam : stimulasi psikososial

Pada sesi ini kegiatan yang dilakukan adalah terapis mengajarkan stimulasi perkembangan aspek psikososial pada guru yang meliputi : memotivasi anak melakukan kegiatan atas inisiatif sendiri, seperti membantu pekerjaan rumah sederhana, memberi kesempatan anak melakukan kreativitas seperti bermain dengan alat-alat rumah tangga, menikmati bermain dengan teman sebaya dengan permainan sesuai jenis kelamin, membantu pekerjaan ibu/ ayah, makan bersama keluarga, bermain peran "berjualan" dengan menggunakan uang buatan sebagai penjual dan pembeli

Setelah mengajarkan kepada guru, terapis mempraktikkan langsung cara stimulasi pada anak, kemudian terapis memberi kesempatan pada guru untuk mempraktikkan stimulasi langsung pada anak. Terapis juga meminta komitmen guru untuk melatih anak bersosialisasi di luar rumah. Terapis juga diharapkan senantiasa memberikan pujian atas keberhasilan keluarga melakukan stimulasi dan keberhasilan anak melakukan keterampilan yang dilatih. Terapis juga mengajarkan orang tua bagaimana cara memberi pujian atas keberhasilan anak melakukan kegiatan, dan bagaimana memotivasi anak untuk tetap mencoba bila belum berhasil melakukan kegiatan

7. Sesi ketujuh : sharing pengalaman

Pada sesi ini kegiatan yang dilakukan adalah terapis menanyakan cara stimulasi yang telah diajarkan guru dan apa manfaatnya bagi anak, kompetensi yang telah dicapai anak serta berbagi pengalaman antar guru mengenai stimulasi perkembangan yang telah dilakukan selama ini

\section{HASIL DAN PEMBAHASAN}

Stimulasi tumbuh kembang mental anak melalui terapi kelompok terapeutik merupakan kegiatan yang bertujuan untuk meningkatkan kesehatan jiwa masyarakat khususnya pada anak prasekolah dan keluarganya. Hal ini sejalan dengan pendapat Allender (2010) yang menjelaskan bahwa kesehatan jiwa masyarakat merupakan pelayanan kesehatan yang bertujuan untuk meningkatkan kesehatan jiwa masyarakat melalui pencegahan gangguan jiwa dan menangani kebutuhan penderita gangguan jiwa.

Pelaksanaan stimulasi tumbuh kembang mental anak melalui terapi kelompok terapeutik dilakukan dengan memberikan kesempatan pada anak untuk berbagi pengalaman, saling membantu satu dengan yang lain dalam melakukan stimulasi perkembangan dan berfokus pada hubungan atau interaksi di dalam kelompok. Stimulasi tumbuh kembang mental anak melalui terapi kelompok untuk meningkatkan kemampuan motorik kasar antara lain dengan cara bermain lompat tali, berjalan mengikuti garis, dan berjalan jinjit. Stimulasi untuk meningkatkan perkembangan motorik halus melalui menulis angka dan huruf, menccocokkan dan menghitung angka, menggambar dengan berbagai sudut pandang Stimulasi untuk perkembangan kognitif antara lain melalui 
kegiatan menggambar bentuk orang dengan enam anggota tubuh, kemampuan bercerita dengan fantasi. Perkembangan bahasa berfokus pada kemampuan anak menjelasakan atau memberikan alasan bila melakukan sesuatu, kemampuan anak bercerita dengan kalimat lengkap. Perkembangan emosi berfokus pada kemampuan anak menunda keinginan atau tidak memaksakan keinginan. Perkembangan spiritual pada kemampuan berdoa sebelum dan sesudah kegiatan.

Berdasarkan hasil kegiatan stimulasi tumbuh kembang mental anak melalui terapi kelompok terapeutik yang dilakukan, diketahui bahwa kemampuan bahasa anak masih rendah, dimana sebagian besar anak belum mampu menjelaskan atau memberikan alasan bila melakukan sesuatu. Hal ini dikarenakan usia sebagaian besar anak masih dibawah 5 tahun, dimana pada usia tersebut perbendaharaan kata yang dimiliki \pm 900 kata dan anak baru dapat membuat kalimat denagn 3-4 kata. Hal ini diperkuat oleh penjelasan Potts dan Mandleco (2012) yang menjelaskan bahwa perkembangan bahasa pada anak usia dini ditandai dengan anak mengerti nama, umur, memnuat kalimat dari 304 kata, banyak bertanya, dan mempunyai kosa kata \pm 900 kata.

Perkembangan aspek spiritual mempunyai nilai tinggi setelah dilakukan stimulasi tumbuh kembang mental anak melalui terapi kelompok terapeutik dilakukan, dimana anak mampu berdoa sebelum dan sesudah kegiatan, beribadah bersama keluarga, dan mengikuti kegiatan keagamaan dalam hal ini agama islam. Hal ini dapat terjadi mengingat lingkungan di sekitar tempat tinggal keluarga adalah lingkungan yang agamais yang mempunyai nilai atau keyakinan kuat dalam menjalankan ibadah atau kegiatan keagamaan seperti pengajian, sekolah mengaji, majelis taklim dan sholat berjamaah. Potter (2005) menjelaskan bahwa lingkungan keluarga merupakan kekuatan eksternal yang menjadi salah satu faktor utama yang mempengaruhi pertumbuhan dan perkembangan anak.

Kemampuan inisiatif anak prasekolah yang mempunnyai nilai tertinggi adalah kemampuan anak untuk berani mengungkapkan bila tidak menyukai sesuatu. Kemampuan ini merupakan salah satu kemampuan inisiatif anak dari aspek psikososial, dimana anak pra sekolah harus dapat mengungkapkan secara verbal tentang perasaannya baik itu senang, sedih, marah, kecewa, bahagia dan sebagainya. Menurut Erikson (dalam Potts dan Mandleco, 2012), karakteristik perkembangan psikososial anak usia dini adalah rasa inisiatif vs rasa bersalah. Keberanian anak untuk mengungkapkan perasaanya membutuhkan dukungan dari keluarga karena biasanya anak akan takut terhadap orang tua bila menyatakan pendapat atau perasaannya yang tidak sesuai dengan orang tua. Selain itu dengan stimulasi tumbuh kembang mental anak melalui terapi kelompok terapeutik, anak prasekolah akan mudah termotivasi untuk mengikuti salah satu teman untuk berani mengungkapkan pendapatnya.

\section{SIMPULAN}

Simulasi tumbuh kembang mental anak melalui terapi kelompok terapeutik dapat meningkatkan perkembangan inisiatif anak prasekolah melalui delapan aspek perkembangan yaitu aspek motorik kasar dan motorik halus, kognitif dan bahasa, emosi dan kepribadian, moral dan spiritual serta aspek psikososial. Tercapainya kompetensi perkembangan pada tahap pra sekolah ini akan menjadi pondasi bagi tahap perkembangan berikutnya. Anak akan siap secara fisik dan mental memasuki usia sekolah.

\section{SARAN}

1. Terapi stimulasi tumbuh kembang mental anak melalui terapi kelompok terapeutik sebaiknya dilakukan sesuai dengan perkembangan usia anak, dengan memperhartikan alat permainan yang digunakan serta cara bermainnya.

2. Keluarga hendaknnya melakukan stimulasi secara terus menerus dan berkesinambungan untuk mencapai perkembangan yang optimal

3. Perawat spesialis jiwa sebagai terapis dalam terapi kelompok terapeutik hendaknya bisa ditempatkan di puskesmas sehingga bisa membantu pelaksanaan terapi ini di masyarakat secara langsung, maupun pelayanan anak usia dini lainnya 
4. Kepada Lembaga Penelitian dan Pengabdian Kepada Masyarakat (LPPM) Universitas Universitas Pahlawan Tuanku Tambusai diharapkan dapat memfasilitasi dan mendukung kegiatan-kegiatan pengabdian dosen seperti ini karena kegiatan ini dapat berkontribusi pada upaya pemerintah untuk meningkatkan derajat kesehatan masyarakat khususnya kualitas hidup lansia.

\section{UCAPAN TERIMA KASIH}

1. Prof. DR. H. Amir Luthfi selaku Rektor Universitas Pahlawan Tuanku Tambusai

2. Dewi Anggriani Harahap, M. Keb selaku Dekan Fakultas Ilmu Kesehatan Universitas Pahlawan Tuanku Tambusai

3. Ns. Apriza, M. Kep selaku Ketua LPPM Universitas Pahlawan Tuanku Tambusai

4. Kepala sekolah, seluruh guru dan murid PAUD/TK Zaid bin Tsabit

\section{DAFTAR PUSTAKA}

Clunn, (1991). Child psychiatric nursing. Philadelphia : Mosby Years Book Inc

Depkes RI. (2007) Stimulasi, deteksi dan intervensi dini tumbuh kembang anak di tingkat pelayanan kesehatan dasar. Jakarta

Direktorat Pendidikan Anak Usia Dini. (2010). Pedoman teknis penyelenggaraan kelompok bermain. Jakarta: Direktorat Pendidikan Anak Usia Dini

Hamid, A.Y.S. (2009) Bunga rampai asuhan keperawatan kesehatan jiwa. Jakarta : EGC

Potter, P.A. \& Perry,A.G. (2005). Fundamental of nursing : concept, process, and practice. Philadelphia : Mosby Years Book Inc.

Reknoningsih, Rahayu. (2014). Efektifitas terapi kelompok terapeutik pra sekolah terhadap perkembangan inisiatif anak usia dini dengan pendekatan model konseptual Hildegard Peplau. Depok: Karya Ilmiah Akhir

Santrock, J.W (2007). Child development (perkembangan anak). Jakarta : Erlangga

Johnson, B.S. (1995). Child, adolescent, and family psychiatric nursing. Philadelphia : J.B. Lippincott Company 